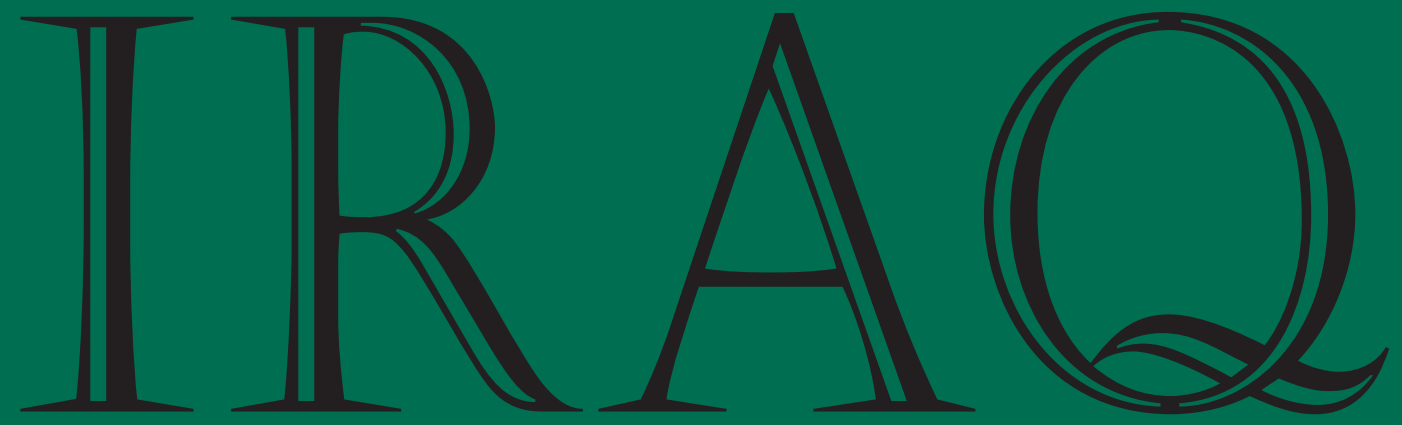

JOURNAL OF THE BRITISH INSTITUTE FOR THE STUDY OF IRAQ(GERTRUDE BELL MEMORIAL)

VOLUME LXXIX • 2017

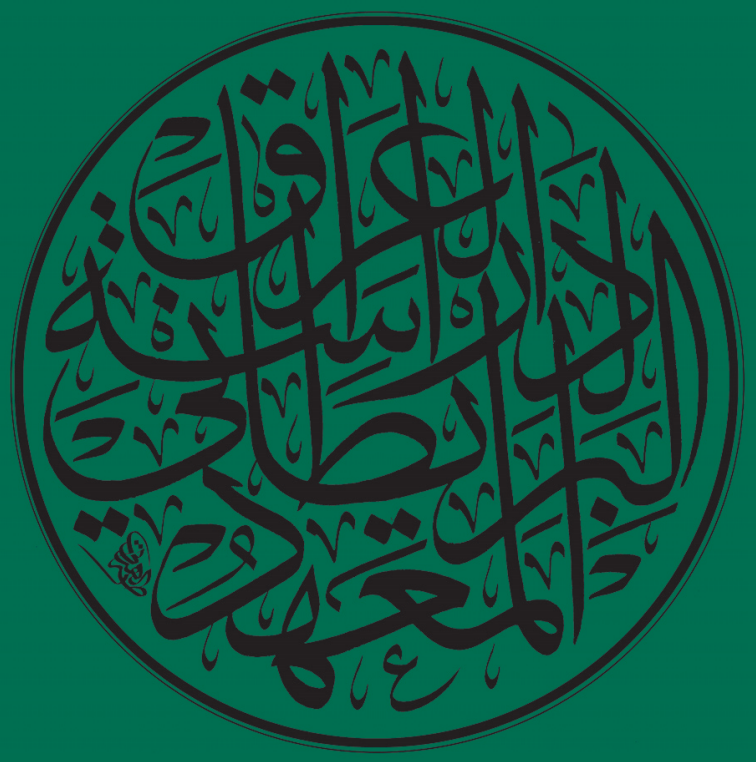

PUBLISHED ON BEHALF OF THE

BRITISH INSTITUTE FOR THE STUDY OF IRAQ

(GERTRUDE BELL MEMORIAL)

ISSN 0021-0889 


\section{THE BRITISH INSTITUTE FOR THE STUDY OF IRAQ \\ (GERTRUDE BELL MEMORIAL) - BISI}

\section{Journal}

$I R A Q$ is a refereed journal devoted to studies of the history, art, archaeology, religion, economic and social life of Iraq, and to a lesser degree of the neighbouring countries where they relate to it, from the earliest times down to about AD 1750. Texts concerning these subjects, with translations and comments, will be considered; exclusively philological articles will not be accepted. Copyright is held by The British Institute for the Study of Iraq.

\section{Contributors}

Articles can be written in English, French or German. Please send your manuscript in both Word (or equivalent) and pdf formats. For refereeing purposes, we need a version in which all identifying information (name, institutional affiliation etc.) is removed; $I R A Q$ uses a double blind refereeing system.

Articles should not exceed 10,000 words (without prior approval from the Editorial Board), and must include:

- an abstract suitable for translation into Arabic;

- a bibliography or full list of references;

- the editors request the name-date system of referencing (e.g., Mallowan 1954);

- and your address and email for academic purposes. These details will be published alongside the article.

Where possible, abbreviations should match those current in The Assyrian Dictionary of the Oriental Institute of the University of Chicago.

Please use a Unicode font if your paper includes special characters such as used in cuneiform transliteration, for example.

Full instructions for contributors, including guidance on bibliographic citation, fonts, and image quality may be found at www.cambridge.org/core/journals/iraq/information/instructions-contributors

Under the direction of the Editorial Board all contributions to the journal are peer-reviewed anonymously by members of the board and by selected experts.

Articles should be sent to the Editor,

Professor Eleanor Robson, e.robson@ucl.ac.uk

\section{Membership of BISI}

Everyone is welcome to become a member of BISI, wherever you live in the world. Joining BISI means becoming part of our work promoting research and education about the history, culture and society of Iraq. For full information on how to join and subscribe to the journal $I R A Q$ visit www.bisi.ac.uk or contact bisi@britac.ac.uk.

\section{Institutional subscriptions to IRAQ}

Please see the inside back cover.

IRAQ is published by Cambridge University Press for The British Institute for the Study of Iraq (Gertrude Bell Memorial).

(C) The British Institute for the Study of Iraq ISSN 0021-0889 


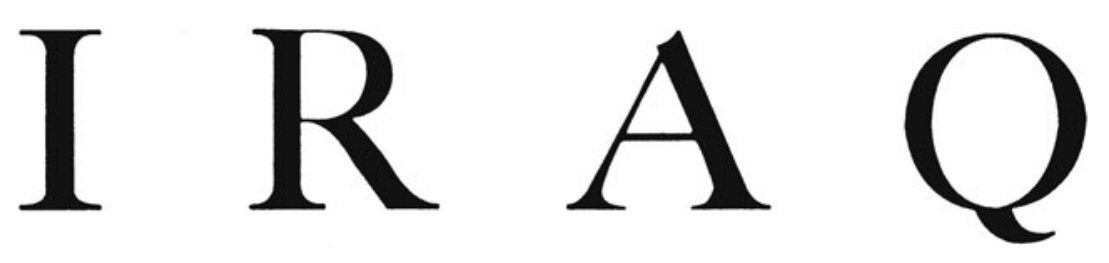

\section{VOLUME LXXIX・2017}

\section{CONTENTS}

E. Robson: Editorial

Ali. Y. Al-Juboori: Recently Discovered Neo-Assyrian Royal Inscriptions from the 3 Review Palace and Nergal Gate of Nineveh

Stuart Campbell, Jane Moon, Robert Killick, Daniel Calderbank, Eleanor

Robson, Mary Shepperson and Fay Slater: Tell Khaiber: An Administrative Centre of the Sealand Period

Jesse Casana and Claudia Glatz: The Land Behind the Land Behind Baghdad: Archaeological Landscapes of the Upper Diyala (Sirwan) River Valley

YaĞMur Heffron: Testing the Middle Ground in Assyro-Anatolian Marriages of the Kärum Period

DAVID KeRTAI: Embellishing the Interior Spaces of Assyria's Royal Palaces: The Bēt Hilāni Reconsidered

Camille Lecompte and Christine Pariselle: Tablettes de la Collection de Michel de Genouillac

Richard Piran McClary: Remembering the Imām Yahyā Ibn Al-Qāsim Mashhad in Mosul

Sam Mirelman: A New Manuscript of Lugal-e, Tablet IV

Julian Edgeworth Reade: The Manufacture, Evaluation and Conservation of Clay Tablets Inscribed in Cuneiform: Traditional Problems and Solutions

Robert Rollinger: Dāduša's Stela and the Vexed Question of Identifying the Main Actors on the Relief

Glenn M. Schwartz, Christopher D. Brinker, Andrew T. Creekmore III, Marian H. Feldman, Alexia Smith and Jill A. Weber: Excavations at Kurd Qaburstan, a Second Millennium B.C. Urban Site on the Erbil Plain

KATHERYn C. Twiss: Animals of the Sealands: Ceremonial Activities in the Southern Mesopotamian "Dark Age"

Mark Altaweel: Some Recent and Current Archaeology in Iraq

PUBLISHED BY THE

\section{BRITISH INSTITUTE FOR THE STUDY OF IRAQ}

(GERTRUDE BELL MEMORIAL)

10 Carlton House Terrace, London SW1Y 5AH

www.bisi.ac.uk

ISSN 0021-0889 